
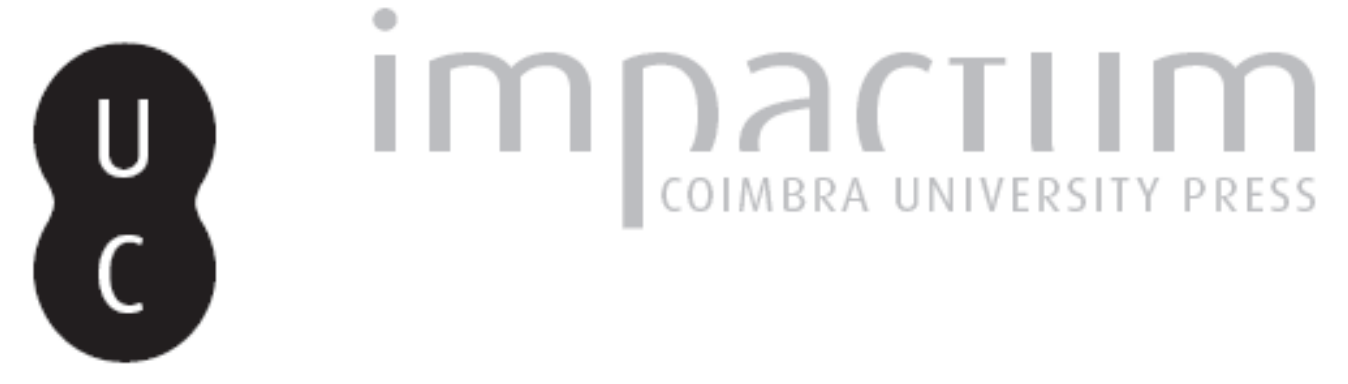

\title{
Socrates on the emotions
}

Autor(es): $\quad$ Brickhouse, Thomas C.; Smith, Nicholas D. $\begin{array}{ll}\text { Publicado por: } & \text { Sociedade Internacional de Platonistas; Imprensa da Universidade de } \\ \text { Coimbra }\end{array}$

URL
persistente: $\quad$ URI:http://hdl.handle.net/10316.2/38744

DOI: $\quad$ DOI:http://dx.doi.org/10.14195/2183-4105_15_1

Accessed : $\quad$ 26-Apr-2023 00:15:33

A navegação consulta e descarregamento dos títulos inseridos nas Bibliotecas Digitais UC Digitalis, UC Pombalina e UC Impactum, pressupõem a aceitação plena e sem reservas dos Termos e Condições de Uso destas Bibliotecas Digitais, disponíveis em https://digitalis.uc.pt/pt-pt/termos.

Conforme exposto nos referidos Termos e Condições de Uso, o descarregamento de títulos de acesso restrito requer uma licença válida de autorização devendo o utilizador aceder ao(s) documento(s) a partir de um endereço de IP da instituição detentora da supramencionada licença.

Ao utilizador é apenas permitido o descarregamento para uso pessoal, pelo que o emprego do(s) título(s) descarregado(s) para outro fim, designadamente comercial, carece de autorização do respetivo autor ou editor da obra.

Na medida em que todas as obras da UC Digitalis se encontram protegidas pelo Código do Direito de Autor e Direitos Conexos e demais legislação aplicável, toda a cópia, parcial ou total, deste documento, nos casos em que é legalmente admitida, deverá conter ou fazer-se acompanhar por este aviso.

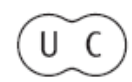


0

\section{Established 1989}

$\infty$ http://platosociety.org/

\section{Papers}

Thomas C. Brickhouse

Nicholas D. Smith

Socrates on the Emotions

Yosef Z. Liebersohn

Socrates, wake up! An analysis and exegesis of the "preface" in Plato's Crito (43a1-b9)

Nathalie Nercam

L'introduction problématique du Timée (17a-27a)

Christopher Moore

'Philosophy' in Plato's Phaedrus

Laura Candiotto

Plato's cosmological medicine in the discourse of Eryximachus in the Symposium. The responsibility of a harmonic technê

Anthony Hooper

Scaling the Ladder

Why the Final Step of the Lover's Ascent is a Generalizing Step

$\varangle$

Z
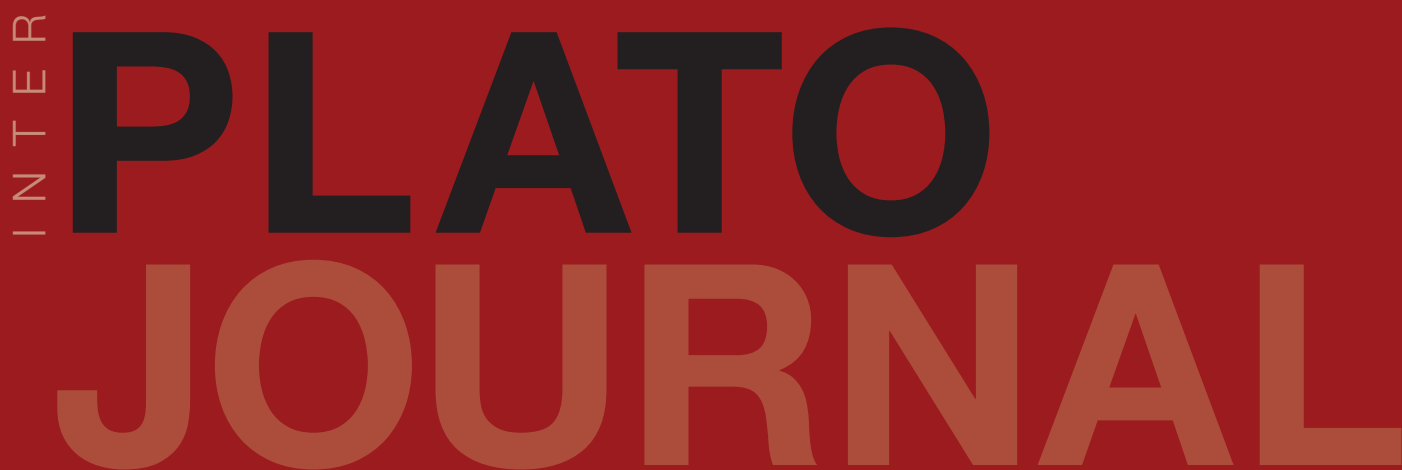

Société Platonicienne Internationale

Associazione Internazionale dei Platonisti

Sociedad Internacional de Platonistas

Internationale

Platon-Gesellschaft

Imprensa da

Universidade

de Coimbra

Coimbra

Universiy

Press 


\section{Socrates}

\section{on the Emotions}

\section{Thomas C. Brickhouse}

Lynchburg College

brickhouse@lynchburg.edu

\section{Nicholas D. Smith}

Lewis \& Clark College

ndsmith@lclark.edu

\section{ABSTRACT}

In Plato's Protagoras, Socrates clearly indicates that he is a cognitivist about the emotions-in other words, he believes that emotions are in some way constituted by cognitive states. It is perhaps because of this that some scholars have claimed that Socrates believes that the only way to change how others feel about things is to engage them in rational discourse, since that is the only way, such scholars claim, to change another's beliefs. But in this paper we show that Socrates is also responsive to, and has various non-rational strategies for dealing with, the many ways in which emotions can cloud our judgment and lead us into poor decision-making. We provide an account of how Socrates can consistently be a cognitivist about emotion and also have more than purely rational strategies for dealing with emotions.
Keywords : Socrates, Emotions, Protagoras, Cognitivism, Intellectualism 


\section{INTRODUCTION: COGNITIVISM AND INTELLECTUALISM}

Though usually reticent about expressing his own opinions, we find Socrates ${ }^{1}$ quite assertive about his own view of fear in the Protagoras:

[Socrates speaking] I say that whether you call it fear (phobos) or dread (deos), it is an expectation (prosdokian) of something bad. (Protagoras 358d5-6²)

Just a bit later, Socrates concludes that the vices we associate with the emotion of fear - cowardice, but also shameful boldness and madness - are all explicable in terms of ignorance of what is and is not to be feared (Protagoras 360b4-c7).

Socrates' argument here seems to be an explicit endorsement of what has come to be known as "cognitivism" about the emotions - the view that emotions just are cognitions. ${ }^{3}$ But as cognitions, we might wonder whether or not they are generated or sustained in the same ways that other cognitions are, and if not, what other processes might be involved. According to several recent works by various scholars, Socrates recognized that some emotions - or at any rate some particular examples of specific emotions that Socrates encounters in his interlocutors in the dialogues - are not as responsive to reason as other kinds of belief are. In her recent study of Plato's characterization of Callicles in the Gorgias, for example, Emily Austin has argued that Callicles' fear of death is non-rational in the sense that it "cannot be altered simply in light of rational argument."4 But why are some beliefs more susceptible and some less susceptible, or not susceptible at all - to rational argument? And how else can one who wishes to challenge such beliefs do so effectively, and how could some process other than reasoning be able to influence what someone believes? It is these questions we seek to answer herein.

\section{ETIOLOGIES OF BELIEF}

Some processes by which human beings generate beliefs are veridically reliable, but it is also a feature of the human condition that some others are not. Those that are veridically reliable include inductions that are based upon adequate observations, deductions from premises that we have carefully considered and whose inferences we have inspected for validity, as well as those derived from ordinary perception in normal conditions. There continues to be debate among both psychologists and epistemologists just what kinds of belief-forming processes really can be counted as reliable, and what the limitations on these might be, but few doubt that human beings have access to at least some reliable cognitive processes. Other belief-forming processes are commonly regarded with a bit more suspicion, including memories of the distant past, and especially beliefs associated with issues of emotional significance for the epistemic agent. Wishful thinking, for example, may well be a source of some beliefs for human beings, but we do not generally regard wishful thinking as a process that grounds rational beliefs. For our purposes in this discussion, then, we will count a belief as rationally caused or sustained if it was caused or sustained by a process we would reasonably regard as veridically reliable. A belief would be non-rationally caused or sustained if it were caused or sustained by a process we would reasonably regard as veridically unreliable. For a belief to be rational in this sense, then, does 
not necessarily require that it be the product of ratiocination or some other form critical thinking; rather, it must be the kind of belief that originates or is preserved among one's beliefs in a way that we would regard as reasonable for the epistemic agent. Again, such beliefs might include, for example, beliefs based on ordinary experience.

Now some understandings of Socrates' motivational intellectualism have held that the only way motivationally significant belief change can occur are through processes that we might generally regard as rational in the above sense. So, famously, Terry Penner once claimed:

There is in Plato's early dialogues [...] a certain "intellectualism" that is quite foreign to the middle and later dialogues [...]. Indeed, that intellectualism, with its implication that only philosophical dialogue can improve one's fellow citizens, is decisively rejected by Plato in the parts of the soul doctrine in the Republic [...]. For Socrates, when people act badly or viciously or even just out of moral weakness, that will be merely a result of intellectual mistake. ${ }^{5}$ (164-5, emphasis in original)

Penner's claim about the unique role for "philosophical dialogue" would only be supported if Socrates also thought that no beliefs are non-rational in terms of what causes or sustains them. More recently, Penner and others who have followed his line of interpretation ${ }^{6}$ have indicated that non-rational desires can play a role in belief-formation. So, for example, we more recently find Naomi Reshotko explaining the view in this way:

[Socratic] intellectualism need only claim that [...] non-intellectualized factors never cause behavior in an unmediated fashion: they cause it by affecting our beliefs. ${ }^{7}$

But even those scholars who have agreed with this much have gone on to differ about how the influence of non-rational desires can influence beliefs. In the view first given by Daniel T. Devereux, which we then took up in our own earlier works, non-rational desires influenced what we believe by representing their targets as goods or benefits to the agent, so that the agent would come to believe that pursuing or obtaining those targets would serve the universally shared desire for benefit, unless some other process interfered with this natural way in which people can come to believe something. ${ }^{8}$ In the view defended by Penner and Reshotko, however, the influence of non-rational elements is not as a direct cause of belief in quite this way. Instead, they play a purely informational role:

In my view, an appetite never plays a role that is more instrumental than any other piece of information that the intellect has used in order to determine what is best to do as motivated by the desire for the good. I hold that appetites are like sense impressions: they are phenomena that help us form judgments, but they do not interact with judgments that have already been formed. ${ }^{9}$

In this account, then, non-rational factors can play a role in how we come to believe something, but the role is not one of direct causation, as it is in the view we have defended. We now believe, however, that Socrates' cognitivism about the emotions provides important insights into how he thinks the non-rational aspects of our moral psychology influence our beliefs. To see how this works, we begin with a passage in 
the Ion that seems to indicate clearly that Socrates recognized that at least some emotions can be caused and sustained through non-rational means of the relevant sort:

Ion: Listen, when I tell a sad story, my eyes are full of tears; and when I tell a story that's frightening or awful, my hair stands on end with fear and my heart leaps.

Socrates: Well, Ion, should we say that this man is in his right mind at times like these: when he's at festivals or celebrations, all dressed up in fancy clothes, with golden crowns, and he weeps, though he's lost none of his finery - or when he's standing among some twenty thousand friendly people and he's frightened, though no one is undressing him or doing him any harm? Is he in his right mind then?

Ion: Lord no, Socrates. Not at all, to tell the truth.

Socrates: And you know that you have the same effects on most of your spectators too, don't you?

Ion: I know very well that we do. (Ion 535 c5-e1; translation slightly modified $)^{10}$

Socrates famously goes on to explain the phenomenon in terms of a kind of "magnetism" with its source in the Muse. But whatever the explanation, it is clear that Socrates thinks the way in which the rhapsode responds to his own tale - a response he also arouses among his listeners in the audience, as well (Ion 535d-e) - is not a rational process in the sense we have identified. Socrates and Ion are clear in their view that such responses are not apt for the specific circumstances (since neither rhapsode nor audience is in any danger of suffering at the moment, yet both react with tears and fears), but the error they make cannot simply be, as Penner put it, "merely a result of intellectual mistake." Moreover, given the way in which the audience's and rhapsode's responses actually come into being, it seems unlikely that the process is one we can understand entirely in terms of the information contained in the performance itself - it is a reaction of a sort whose peculiarities do not seem likely to be fully explicable in terms of their informational content.

Taking Socrates' cognitivism about the emotions into account, moreover, it must follow that what occurs within the rhapsode and also the affected members of his audience is that they, at least temporarily, come to believe that they are witnessing or experiencing something bad. But in what sense do they really believe this? Do they not know that they are, as Socrates puts it, "among some twenty thousand friendly people" and not actually at any risk at all of being done any of the harm described in the narrative? Their reaction is so puzzling that Socrates insists the rhapsode and audience must go (at least a little) out of their right minds in order to have such a thing occur.

Two options seem to present themselves here: one is that those involved with the rhapsode's performance somehow undergo a change in what they believe, temporarily (at least) losing contact with the real world and coming to believe that, instead, they are actually inhabiting the world described in the rhapsode's tales. The other is that the rhapsode opens up an alternative cognitive world that somehow comes into being alongside or along with the person's ordinary cognitions, and the person somehow manages, all the while still being aware that he or she is at a performance, to believe that he or she is at the same time (and obviously impossibly) also inhabiting the world described in the rhapsode's exciting narrative. 
Socrates never reveals in the Ion exactly which of these options he thinks is occurring to the rhapsode or his audience, but Ion's own self-description seems to indicate some version of the latter option. Immediately following the last quotation, we find Ion explaining how he pays attention to his audience's reactions:

Ion: I look down at them every time from up on the rostrum, and they're crying and looking terrified, and as the stories are told they are filled with amazement. You see I must keep my wits and pay close attention to them: if I start crying, I will laugh as I take their money, but if they laugh, I shall cry at having lost money. (Ion 535e1-6)

Socrates immediately goes on to explain what is happening to the audience in terms of his magnetic ring analogy, but he never expresses any doubt about Ion's claim to be able to achieve the strange form of cognitive strabismus by which he both feels the same emotions as he induces in his audience but also attends carefully to the fact that he is doing so from "up on the rostrum" (and thus plainly not on some ancient battlefield, for example). If this "two cognitive worlds" understanding of what is happening is correct, then the rhapsode both experiences and shares the cognitive world of his tale with his audience and somehow manages to get them to focus on this cognitive world rather than the ordinary cognitive world to which they might return at any moment (and to which, in order to make his money, the rhapsode wants them not to return, for as long as he relates his stories). The rhapsode himself, however, somehow manages to experience both of these worlds at once: he cries himself and feels the emotions appropriate to the story, but also at the same time attends in real time, as it were, to the way his audience is reacting.

When Socrates describes both the rhapsode and the audience as being out of their minds, then, he must mean that both are in some way experiencing both cognitive worlds, even if there is some difference of focus between the rhapsode and his audience in terms of which world is getting (most of?) the person's immediate attention. With a successful performance, the audience clearly reacts in a way that is appropriate to the cognitive world depicted in the story. Does that mean, however, that they lose all contact with the real world? This seems too implausible to attribute to Socrates - after all, if a member of the audience, terrified as they are told of Achilles' deadly advance upon Hector, were asked, "What, is Achilles stalking you?" one can easily imagine the affected audience member's impatient reply: "Of course not, but shut up and listen to the story, for heaven's sake!" We see no reason to think that the phenomenon of going out of one's mind at a theatrical performance needs to involve a complete break with ordinary cognition. Instead, then, it is that one simply experiences an alternative to the ordinary world and shifts focus to that other, imagined world. As Ion's case amply shows, one can actually form both beliefs and emotions based on what is presented to the imagination. Of course, what one who has heard Ion "really" believes, that is, believes about the actual world remains, in some sense, readily available to her.

But if all of this is right, it is worth emphasizing that the specific way that the rhapsode and his story-telling create these emotions in the audience is not anything like rational persuasion - and also not simply a matter of providing the audience with new information. Instead, the rhapsode uses a non-rational method (exceptionally vivid story-telling) to 
create what Plato would later demean as a mere image or mimicry of reality, and induces his audience to shift their focus away from the ordinary world and to attend instead to this other alternative. Given cognitivism about emotions, moreover, the audience develops the "expectation of something bad" that has as its intentional object only aspects of the fictive world that belongs to the rhapsode's story.

What Ion relates about his power to affect audiences obviously provides one putative source for the kind of process we have identified as non-rational belief formation. The beliefs Ion can produce are plainly not the result of reliable cognitive processes. Of course, the Ion's example of non-rational belief formation is not the one in the "Socratic dialogues" that has received the most scholarly attention. That distinction goes to the Protagoras. There we find Socrates discussing the sources that "the many" think cause even people with knowledge of what they should do to act badly. These include thumos, hedone, lupè, erōs, and phobos (352b). Now, some of these seem to designate emotional conditions (thumos, phobos), which, again, we know Socrates regards as cognitive states. The effect of this would be that putative cases of akrasia involving thumos or phobos would have to be cases of the agent suffering from conflicting cognitive states, one of which would proscribe some action, and the other of which would prescribe that action. Insofar as one of these beliefs (presumably the one that qualifies as thumos or phobos, by which the agent's putative "knowledge" is overwhelmed) is non-rational, it is not surprising that it is epistemically inapt - false, and the result of an unreliable cognitive process. The action one takes on the basis of false and unreasonable beliefs is not likely to go well, and if it does happen to go well, it will be merely by luck.
A putatively "akratic" agent, acting under thumos or phobos, would presumably believe that he should not act in some way $\varphi$, but would also believe (thumotically or phobically) that he should. But, since Socrates holds that knowledge cannot be "pushed around like a slave," such a person could not possibly know that he should not do $\varphi$. Moreover, Socratic intellectualism requires that one always does what one believes is best for one, from among present options of which one is aware at the time of action, and so it must be that the "akratic" person's thumotic or phobic belief is dominant at the time of action. So, this picture leads to the Socratic denial of synchronic belief akrasia. It does allow, however, for diachronic belief akrasia. The question we need to ask, however, is this: Since the emotions just are beliefs, according to Socratic cognitivism about the emotions, we might reasonably wonder how such beliefs come to exist in the first place. Granting that at least some emotions can have non-rational sources, what are these sources?

A passage in the Charmides (167e1-5) seems to indicate that human beings experience different kinds of desire, which target different sorts of goals. These include appetite (epithumia), which aims at pleasure, wish (boulessis), which aims at what is good, and love (erōs), which aims at what is beautiful. Each of these seems to have an aversive alternative, as well: we avoid pains, what is bad, and what is ugly. Our natural attractions and aversions, we contend, are the grounds for a variety of non-rational beliefs: Insofar as something seems or promises to be pleasurable, beneficial, or beautiful, the agent will be naturally inclined to believe it to be something good; and insofar as something seems to be painful, detrimental, or ugly, the agent will be naturally inclined to believe it to be something bad. Unless the natural inclination to believe in such cases is 
mitigated or defeated by some other (for example, rational) belief-forming process, one will form beliefs about goods and evils accordingly. The beliefs created by these natural attractions and aversions, because they derive from non-rational processes, are veridically unreliable, but are also to some degree (by their nature as non-rational) resistant to rational persuasion and other belief-forming processes. In this respect, beliefs about goods and evils formed by natural attractions and aversions without the benefit of deliberation and reflection are like beliefs formed by the vividness of Ion's story-telling. Moreover, once such a belief has been acquired, the one who has such a belief is likely to make further judgments, based on the non-rational belief, thereby compounding the problem. But Socrates (in the Gorgias, particularly) shows that he thinks that the non-rational processes by which such beliefs are formed can be strengthened or weakened by certain practices. Disciplining the appetites, for example, is likely not only to keep in check one's ability to lead one to end up believing falsely that some anticipated pleasure is really a good thing, but also makes one better able to attend to other belief-forming processes, including especially reasoning. It is important to emphasize that although an emotion, such as fear, that results from an aversion to pain, is a cognitive state, what produces the emotion is not merely some "inner" neutral event without any causal connection to cognition and about which it is always within an agent's power to decide whether the "inner event" is good or bad. Again, if such an event is an attraction, the agent will believe the object of the attraction is a good unless the attraction is counter-acted by other belief-forming process; and if such an event is an aversion, the agent will believe the object of the aversion is an evil, unless the aversion is counter-acted by other belief-forming process. Accordingly, in relation to the emotions, keeping these particular non-rational belief forming processes, such as appetite and erōs, in a disciplined condition will make one less likely to experience inapt emotions.

So when Socrates disagrees with "the many" in the Protagoras when they claim that thumos, hedone, lupè, erōs, and phobos all create the possibility for synchronic belief akrasia, it is because he thinks that some of these (thumos, phobos) are themselves already cognitive and cannot thus be instances in which an agent acts in a way that is contrary to what the agent believes. In the other cases (hedonē, lupè, erōs), the phenomena said to defeat the agent's belief actually do their work by creating beliefs non-rationally - beliefs which, at least for the moment of action, replace the belief held by the agent and which "the many" see as being overcome in putatively akratic actions. But Socrates seems to think that the original belief is actually replaced as a result of the way the agent determines what is really in the agent's best interest at the time of action. The result is that the agent always acts in the way the agent thinks is best for the agent at the time of action - but in cases "the many" think are akratic, the belief held by the agent at the time of acting is the product of a non-rational belief-forming process, one grounded in natural attractions or aversions, and not defeated by other belief-forming processes including especially the ones that may have led the agent to think otherwise earlier.

But as we noted in our discussion of the Ion, it does not need to follow from all of this that the agent, in changing beliefs in this way, continues to have, as it were, access to only one single cognitive world at a given time. It may be that agents can experience two (or more?) cognitive worlds that are inconsistent with one another, and how one reacts or behaves at a giv- 
en time is to be explained, not by an appeal to one single coherent cognitive system somehow losing contrary beliefs from the system altogether, but by something like the way in which the agent comes to focus on the different views he or she could hold. Putative akratics are not really akratic in the way "the many" supposed, in this picture, even if the agents still have, within their cognitive systems all told, access to all of the reasons why they thought it best not to act as they end up acting, and even if they also continue to have some cognitive access to the very belief as to how they should act that would rationally follow from such reasons. In suggesting that one who has a belief that is part of one system still "has access to" to another which he accepts, we are not suggesting that he or she could not temporarily find the one so compelling that he or she utterly loses track of the other. Indeed, this is what commonly happens in diachronic belief akrasia. "The many" are not wrong to think that the shift is to be explained by such things as thumos, hedone, lupè, erōs, and phobos. But what "the many" have missed is that putatively akratic agents continue in every case to act in the ways they believe is best for them, given the options of which they are aware under the circumstances. So-called akratics behave as if they have suddenly forgotten everything they believed before their allegedly akratic actions. But, in the view we are proposing, it need not be that they have lost all cognitive access to their former beliefs. For one thing, we are not surprised when all of their former beliefs come back to haunt them, as they feel remorse for what they have done and think that what they have done is wrong. But something has certainly disturbed the way in which they create and sustain beliefs about what they should do. Our account has it that non-rational belief-forming and belief-supporting processes, based in our natural attractions and aversions, have intervened in ways that can make someone lose their focus on what they had come to believe more rationally, and come to focus instead on the beliefs to which these attractions and aversions naturally incline us. Socratic motivational intellectualism (always acting in the way we believe is best for us) is preserved, and "the many" are thus mistaken about akrasia. But the moral psychology thus revealed is obviously a good deal more complicated than what is imagined in Penner's purely informational version.

\section{IRRATIONALISM AND RESISTANCE TO REASON}

If there are beliefs whose causal origin or continued ground is other than the more familiar rational epistemic origins and grounds, then that would help to explain why, in so many of our dialogues, we find recalcitrant interlocutors who appear to continue to believe things they are not able to justify to Socrates, or refrain from accepting things that Socrates shows them they have better evidence for accepting than what they have claimed to accept. Examples of such episodes in our texts are so familiar we need here only to look briefly at two texts to get some sense of their variety. The following examples are, accordingly, not in any way intended to be exhaustive, but only illustrative of some different ways in which this sort of interlocutory recalcitrance can appear.

(1) Apology. In the Apology, we find Socrates straining to explain to his jurors why he has become such an object of hatred. It was all because of his questioning of others, he explains, who claimed to be wise when they actually were not. "This very investigation, Athenians, has generated for me a great deal of hatred, which is most difficult to handle and hard to bear, and 
the result has been a lot of slandering, and the claim made that I'm "wise". (Apology 22e6$-23 a 3)^{11}$

We might wonder why such hatred would be "most difficult to handle and hard to bear" by someone as gifted in reasoning as Socrates is. If changes of ethical belief were always simply to be achieved by "philosophical dialogue," as Penner has it, we see no reason why Socrates would struggle to deal with the hatred he has encountered. He might simply speak sensibly to those who react badly, and we would expect happy results to the same degree as Socrates' arguments present good justification. But that, it seems, is not at all how things have gone for Socrates, neither with his detractors, nor with his jurors, with whom Socrates finds himself pleading not to judge him in anger (36b6-d1, see also $34 \mathrm{c} 7-\mathrm{d} 1$ ).

The Apology also gives some examples of Socrates' awareness of unreason based on the effects of fear. An important theme in what Socrates says to his jurors is that he will not, in spite of what they may expect from him, do anything as a result of a fear of death. Socrates' repeatedly making this point (see, e.g., 28b3-29c1, 32a4-e1) makes plain that he is well aware of how common it is for others to act in ways that are the result of their fear of death. But Socrates insists that those who act from the fear of death thus expose their ignorance, "for no one knows whether death happens to be the greatest of all goods for humanity, but people fear it because they're completely convinced that it's the greatest of evils" (29a9-b1). On the contrary, as far as Socrates himself is concerned,

But in this respect, too, men, I'm probably different from most people. While I don't really know about the things in Hades, I don't think I know. But I do know that it's evil and disgraceful to do what's wrong and to disobey one's superior, whether god or man. Rather than those things that I know are bad, I'll never run from nor fear those things that may turn out to be good. (29b5-c1)

Here, again, Socrates emphasizes that he is "different from most people," because he realizes that most people often act in the ways they do because of what he plainly regards as an irrational fear of death. It is important to underscore that Socrates is not suggesting that most people have a mere false belief about what happens after death, as if they have simply accepted the wrong information about what happens after death, perhaps from the poets or some other source. Nor is Socrates only accusing them of being unreflective about what happens at death, though they are surely that. That he compares his own readiness to face death at the hands of the court rather than disobey the god to his readiness to face death on the battlefield rather than disobey his commanders (28d6-29a1) shows us that he thinks someone who is able to overcome or abandon a fear in favor of a desire to do what he thinks is right must have a certain psychic strength that enables the soul to form and hold onto the right belief. Thus, contrary to the informational view of Socratic motivational intellectualism the lesson of the Apology on the fear of death cannot very well be that those who fear death as if it were "the greatest evil" merely need to acquire the right information. But given that their fear maintains an irrational hold over them, it is obvious that Socrates does not think he can simply explain, as he does, how and why such a fear is irrational, and expect that those susceptible to having and acting on such fears will so simply be relieved of their irrationality. If only it were so easy! 
(2) Gorgias. As we noted at the outset, there has already been a careful recent study of Callicles' behavior in the Gorgias that contends his behavior must be understood as being the result of fear - specifically, Callicles' "crippling fear of death," as Emily Austin puts it. ${ }^{12}$ It is this irrational fear, according to Austin, that makes Callicles unable to accept Socrates' arguments, even though Callicles can actually see the rational force of Socrates' arguments. The critical passage for seeing this, as Austin notes, is at $513 \mathrm{c} 4-\mathrm{d} 1$, where Callicles seems simply to concede everything that Socrates has argued. Nonetheless, he complains that he is still "not quite persuaded". Socrates playfully suggests that Callicles' lack of rational response is due to yet another non-rational source of beliefs: love:

Callicles: I don't know how it is that I think you're right, Socrates, but the thing that happens to most people has happened to me: I'm not really persuaded by you. Socrates: It's your love (erōs) for the people, Callicles, existing in your soul, that stands against me. But if we closely examine these matters often and in a better way, you'll be persuaded. (513c4-d1)

Austin contends that it is really Callicles' fear of death that puts him beyond rational persuasion at this moment. But as we said in the last section, we do not doubt that erōs, too, has the potential to generate and sustain beliefs in ways that are veridically unreliable. Either explanation, accordingly, would equally serve to explain why, in spite of his ability to follow reasoning, Callicles would continue to believe in a way that was contrary to the reasons of which he becomes aware in his discussion with Socrates.

Our very brief citations of episodes in these two dialogues are enough, we think, to give samples of at least three of the sources of ir- rationality in people Socrates tries to persuade: anger, fear, and erōs. If we recall the list provided by "the many" for why, in their view, people behave akratically, we will find these three items familiar, but they leave the full list incomplete. But resistance to reason may be found elsewhere in our texts, as well, and we might find that proper explanations of such irrationalism would give us reason to increase our list of explanations. Callicles says that what has happened with him also "happens to most people". Callicles also complains that in the discussions with Gorgias and Polus immediately preceding his own interaction with Socrates, the others had simply made the concessions they did out of shame, rather than genuine conviction (482c5-483a2).

Did "the thing that happens to most people" also happen to Euthyphro, who makes a hasty retreat from his conversation with Socrates, but does not give any clear indication that he has been persuaded by anything in his conversation with Socrates? If he remains unpersuaded, why is that? And how about Crito, in the dialogue that bears his name? He is certainly shown to accede to Socrates' arguments, but he seems to do so mostly in silence, which might leave us somewhat uneasy about his level of real commitment to those arguments. In many of the dialogues, one is left wondering at just how much difference the discussion has made to the interlocutors. At best, Socrates is able to bring them to the very good result (in his view) that they recognize in themselves a state of aporia. We think, for example, this result may be found in the Laches, Lysis, and especially Hippias Minor where the aporia achieved seems even to infect Socrates himself (see 372a6-e6, 376b8-c6). Perhaps in Republic I, Socrates manages even to begin to win over the most recalcitrant of any of the interlocutors we meet in Plato's dialogues, but it is, at best, only a beginning ${ }^{13}$ 
- Thrasymachus can hardly be supposed to have been convinced by anything Socrates has said. Perhaps different diagnoses will be needed to explicate well the lack of rational responses we find in the different dialogues. But that we find such irrational responses can hardly be doubted.

\section{VARIABILITY OF RATIONALITY}

We first noted that Socrates is a cognitivist about the emotions, and have now offered an account of how he can maintain this position and also understand that the emotions can create impediments to reasoning, on the ground that the beliefs in which the emotions consist can be the result of non-rational belief-forming processes, and are thus veridically unreliable. ${ }^{14}$ These processes, we claim, are the ways in which our very natural attractions and aversions function psychologically: They present to the soul representations of what is best for us, inclining the agent to come to believe that doing whatever the attraction or aversion indicates actually is the best thing for the agent to do under the circumstances, given the options of which the agent is presently aware. The inclination to come to such a belief is, however, defeasible; the agent might be able to consider some contrary evidence that convinces him or her that the inclination in question would be a mistake. An example of this kind of process would be familiar enough to most of us: Imagine the dieter naturally attracted to some obviously well-crafted piece of pastry, and finding himself inclined to eat it. But then, the agent reminds himself that he is supposed to be on a diet and thus to avoid eating such things as the pastry he has just now been offered. Perhaps with some reluctance, the dieter thus decides to decline the pastry, believing that not eating it would be the best thing for him in this instance. Our natural attractions to food and drink may be conceived as examples of what Socrates calls appetites in the Charmides passage where he distinguishes different kinds of desire. We can conceive of a different sort of example that might involve each of our other natural forms of attraction or aversion, such as those that derive from erōs, ${ }^{15}$ or those involving our aversion to the approach of something bad, which would incline us to form the belief that is fear.

But if, as we have claimed, such attractions and aversions are themselves entirely natural for us, and if, as we have also claimed, the way these work is to incline us to generate and accept certain beliefs, why is it that some people seem better and some worse, in terms of the rational fallibilities associated with these non-rational processes? The fearful person, as we all know, is much more likely to form false beliefs about threats in his or her environment; the courageous person is much less likely to make such mistakes. As Socrates puts it in the Protagoras,

[Socrates speaking] Now then; that through which cowardly people are cowardly, do you call it cowardice or courage?

[Protagoras] Cowardice.

And aren't cowards shown to be so through their ignorance of what is to be feared?

Absolutely.

So they are cowards because of that ignorance.

He agreed.

So, can we conclude that cowardice is ignorance of what is and is not to be feared? He nodded. (360c1-7) 
Those who operate in ignorance, we know, will mostly fail to do well, except in rare instances when dumb luck might favor them. Now we are asking a different question, however: Socrates claims that cowards are the way they are because of ignorance. But how and why is it that some people become much more ignorant than others? How, that is, do cowardly people become cowardly and courageous people become the opposite?

The obvious answer to this question is to go back to Socrates' discussion, also in the Protagoras, about the wondrous advantages that would accrue to us if only we could come to achieve what he calls the "craft of measurement" (metrētikē techne- $-356 \mathrm{~d} 4$ and following). It is this craft, he says, that would allow its possessor to defeat the "power of appearances".

[Socrates speaking] While the power of appearance often makes us wander all over the place in confusion, often changing our minds about the same things and regretting our actions and choices with respect to things large and small the craft of measurement in contrast, would make the appearances lose their power by showing us the truth, would give us peace of mind firmly rooted in the truth and would save our life. (356d4-e2; translation slightly modified and our emphasis)

In our Socratic Moral Psychology, we explained that our natural attractions and aversions create what Socrates here calls the "power of appearance," making things to which we are attracted or averse seem greater in value (positive or negative, respectively) when the attraction or aversion is particularly active (e.g. when we are hungry and see the pastry) and when the objects of such attractions or aversions are more proximate, spatially or temporally. The difference between the coward and the courageous person, then, can be drawn in terms of the former lacking and the latter having the craft of measurement.

But this cannot be the whole story, nor is it enough to answer the question we just asked. After all, it seems the craft of measurement that would be our savior in life is nothing other than the knowledge that would be constitutive of wisdom (see 360c7-d5). But as we know from the case of Socrates himself, such wisdom is, at best, in very short supply among human beings. Socrates, after all, is the one who always claims to lack such wisdom. Indeed, he has been identified by the Delphic oracle as the wisest of men only because of his awareness of his own ignorance (see Apology 23a5-b4). It would appear, accordingly, that Socrates himself lacks the craft of measurement; and if no one is wiser than Socrates, then no one else, it seems, has been so fortunate as to come to have that craft. But even in the Apology, Socrates claims that he is wiser than those he interrogates who think they are wise when they are not. And, as we have seen, he is also not as likely to do anything shameful out of a fear of death. How is it that some people, then, become very cowardly and fearful, but others - even though they lack the craft of measurement - can somehow overcome or minimize the distorting effects of the power of appearance that comes to us through our very natural attractions and aversions? How can some people manage at least for the most part to avoid the errors of the fearful coward?

The answer to this question, it seems, cannot be simply to encourage those who wish to do better than cowards simply to go and acquire the craft of measurement. Such an acquisition, after all, turns out to be no easy task, 
and may well not prove even to be possible for ordinary human beings. ${ }^{16}$ But the examples of Socrates and many others who are steadfast in battle or self-controlled in other admirable ways seem to indicate that the ignorance that so deeply infects the coward may be avoidable without the actual possession of the craft of measurement, at least to a degree.

Now it is a commonplace to note that Socrates does not at all think we should give up on the quest to become virtuous. On the contrary, as he characterizes his ordinary activities in Athens to his jurors, he claims that he is exhorting his fellow citizens always to pursue virtue, and to value it more highly than anything else (see Apology 29d7-30b2). So he obviously believes there is real value to be achieved through the pursuit of virtue - even if its final acquisition may not be in the offing for us. This, we may assume, is why he thinks "the unexamined life is not worth living for men" (Apology 38a5-6).

But this "intellectualism", as it has been called, is not the only advice Socrates has for others, and it is not the only advice that he makes with an eye to avoiding the errors that our natural attractions and aversions can lead us into. As we have now noted several times, the main problem with the ways in which these things work in us is that the processes involved are non-rational. Socrates advocates a much greater commitment to the rational life than most of his fellow citizens actually followed, because he realized that the life of reason is one very important way in which a person can defeat "the power of appearance" even without the fully achieved "craft of measurement". In essence, one can achieve some balance even in the face of some powerful appearance simply by allowing oneself to consider contrary evidence one may have for what one is naturally inclined to do - evidence provided by more rational and epistemically (and ethically) reliable cognitive processes.

As we have seen, however, the more reliable cognitive processes are not always sufficient by themselves to address and correct the errors created by non-rational and veridically unreliable processes within us. But with specific reference to these processes, Socrates also has additional advice, which we find him offering to Callicles, who as we have seen is clearly characterized as someone with very serious problems deriving from non-rational processes. To Callicles, Socrates advises a strategy that is not as obviously "intellectualist", though one that we claim is completely consonant with Socratic intellectualism:

Socrates: And isn't it just the same way with the soul, my excellent friend? As long as it is corrupt, in that it's foolish, undisciplined, unjust and impious, it should be kept away from its appetites and not be permitted to do anything other than what will make it better. Do you agree or not? Callicles: I agree.

Socrates: For this is no doubt better for the soul itself?

Callicles: Yes, it is.

Socrates: Now, isn't keeping it away from what it has an appetite for, disciplining it?

Callicles: Yes.

Socrates: So to be disciplined is better for the soul than lack of discipline, which is what you yourself were thinking just now.

Callicles: I don't know what in the world you mean, Socrates. Ask someone else. Socrates: This fellow won't put up with being benefited and with his undergoing the very thing the discussion's about, with being disciplined! (505b1-c4) 
It appears that Socrates' "diagnosis" of what is wrong with Callicles is that the younger sophist has allowed his appetites to get out of control, with the result that his soul now lacks discipline. It could hardly be clearer that Socrates regards this as the source of Callicles' irrationality, which he noted as soon as Callicles entered the discussion. It is this lack of discipline in Callicles' soul, we may now see, that causes his soul to be so out of harmony with himself, shifting back and forth (481d5-482c3), and needing Socrates to encourage him to remain calm while they converse (see esp. 503d5). We may conclude that even though there is an important place for rational persuasion in his conversations, Socrates also is quite aware of the processes by which non-rational beliefs come into being and make the person who has them less likely to remain calm and open to the more reliable cognitive processes, including especially those involved in rational deliberation and dialogue.

Earlier in this section, we asked why some people who lack the craft of measurement are so much more likely than others to be susceptible to the processes that generate and sustain non-rational beliefs. We are now in a position to answer that question: the more we keep our appetites - those natural attractions and aversions we have been discussing - in a disciplined condition, the more able we will be to engage in and appreciate the epistemic value of reasoning. But the more one indulges those natural attractions and aversions, the stronger their role in belief-production becomes, with the effect that one becomes increasingly less responsive to reason in one's cognitive processes. It is this condition, we claim, that Socrates has in mind when he says that certain kinds of wrongdoing damage the soul. And at the most bitter end of such damage, Socrates seems to think, one's soul can be damaged beyond any hope of repair - ruined. ${ }^{17}$

\section{REMEDIATION OF IRRATIONALITY}

At the very end of the last passage we quoted, Socrates indicates that at least part of what he is trying to do with Callicles is to help the younger man become more disciplined in his soul. Given that the procedure he seems to be using is conversational, it is not surprising that scholars have understood Socrates' "therapy" here in purely rational terms: His "punishment" of Callicles is to be understood entirely in terms of philosophical dialectic. ${ }^{18}$ But our response to this line of interpretation should at this point be obvious: the kind of dialectic Socrates is using here does not seem to be well understood if we think of it in purely rationalistic terms. Instead, we think we should take more seriously, as other scholars have more recently done, ${ }^{19}$ the idea that an important part of what Socrates attempts to do in his conversations is to shame people whose pretense of wisdom has put them at risk of even further damage to their souls. Callicles himself is hardly unaware of this aspect of what Socrates is up to: after all, Callicles' initial complaint against Socrates' discussions with Gorgias and then Polus is that Socrates had managed to shame the others into making the concessions that they made to his arguments (see 482c5-483a2). Socrates himself never denies the charge that he uses shame in his conversations; indeed, elsewhere, we find him explicitly claiming to do precisely this:

If [someone to whom I am speaking] doesn't appear to me to have acquired virtue but says he has, I'll shame him becau- 
se he attaches greater value to what's of less value and takes what's inferior to be more important. (Apology 29e5-30a2)

Socrates' description of those who earn such shaming from him is curiously reminiscent of a brief description in Homer's Iliad:

But Zeus the son of Kronos stole away the wits of Glaukos

who exchanged with Diomedes the son of Tydeus armour

of gold for bronze, for nine oxen's worth the worth of a hundred. (Iliad VI. 234-6; trans. Lattimore)

Like Homer, Socrates, too, regards those who would trade "gold for bronze" as being out of their wits, not in their right minds, and we have been exploring herein the ways in which such irrationality can get hold of agents and lead them into making decisions they should not make, and which will be damaging to them. As in some of the cases we have been talking about, Glaukos makes his witless decision in the context of an emotional moment - when he takes himself to be renewing vows of guest-friendship with the grandson of a man who had sworn friendship with Glaukos's grandfather.

So Socrates thinks that the pretense of wisdom deserves shaming, and in the Apol$o g y$, too - , just as we see in the Gorgias when he talks with Callicles, Socrates connects the shaming with questioning, examining, and refutation (Apology 29e5). Those who are questioned, examined, and refuted by Socrates, as we often see, find themselves ashamed, and our texts provide several vivid examples of how Socrates' interlocutors react. Perhaps the most famous example of this appears in Book I of the Republic:
Thrasymachus agreed to all this, not easily as I'm telling it, but reluctantly with toil, trouble, and - since it was summer - a quantity of sweat that was a wonder to behold. And then I saw something I'd never seen before - Thrasymachus blushing. (Republic I. 350c12-d3)

Plato's Socrates, then, is well aware of this effect on his interlocutors, and as we can see from his own description of what he does, it is not simply a foreseeable, but is, at least in some cases, an intentional outcome of his engagements with others. Those who become ashamed, plainly, do not find the experience at all pleasant. In fact, some of those whom Socrates shames respond, too, with anger and hatred, as we have already seen. These other responses, we may reasonably expect, are not at all ones that Socrates intends, and when they do occur, as he says (see Apology 22e6-23a3, quoted above in section III), he finds it "most difficult to handle and hard to bear."

But even if Socrates does not always manage to get the reactions he seeks from others, it should now be clear that when he intends to shame one of his interlocutors, we should understand this as operating at a different level, or working on a different element of the interlocutor's psychology, than the purely rational content of his discussions. Persuasion would be much easier, obviously, if one in possession of a strong argument were using that argument on another whose rationality were optimal and unimpeded. As Socrates was well aware, however, such unimpeded rationality is not always what one can expect from an interlocutor, and when that interlocutor becomes recalcitrant because of some non-rational factor, Socrates understands that an application of the unpleasant experience of shame may make the other person more ready to listen to reason. The ap- 
plication of shame adds an important social dimension to persuasion. ${ }^{20}$

Imagine, accordingly, two soldiers waiting on the city walls. Both had volunteered for this duty, believing that it was the best thing they could do, given their great debt to the city. As the enemy approaches, however, one of them cries out and seems on the verge of abandoning his post. The other, remaining steadfast, protests:

Did you not only yesterday say that "wherever someone stations himself, believing it to be best or where someone has been stationed by his commander [...] he must remain there to face danger, not weighing death or anything else more than disgrace"? Do you now plan to run back to your beloved wife and children, marked for life as a pathetic coward? Do you think they will want to be held in the arms of such a worthless specimen? Or perhaps you suppose your parents will have you, and not feel only disgust and shame at their own failure to raise you well enough to be a man instead of a cowering child? Run away, if you like, but do not suppose that when you are done running that you will still have family, or friends, or fellow citizens with whom to consort - for neither will you be allowed even so much as to be a citizen here, if you cannot at least be a man first! (Material in quotations is Apology 28d5-9)

The argument the braver man offers to his tremulous colleague obviously has significant evidential content, but we contend that it is equally obvious that the persuasion intended here operates just as much by attempting to induce a sense of shame in the fearful man. If the frightened man can become aware of the shameful elements in what he is about to do, he will also become more able to appreciate other reasons why it is not actually in his best interest to run away, in spite of the approach of the enemy. Here the fact that he will feel shame if he runs away serves a consideration that should help persuade him to do the right thing. But shame may also serve as a mild chastisement that, for one who has a sense of shame, actually serves to weaken the inclination to see fleeing as a great good. When it functions in this second way, as a form of chastisement, shame can help us to control our non-rational capacities and bring our soul into a more disciplined condition.

But both usages of shame have their limits as a tools for encouraging right conduct, for there are some whose sense of shame seems not to be especially responsive, or which may not exist at all. Earlier, we gestured at Socrates' belief that souls can be damaged by allowing the appetites to go out of control and become undisciplined. The more this lack of discipline takes hold in a soul, the less even shame may have an effect. For more extreme cases of wrongdoing and for wrongdoers whose damaged souls have become increasingly intractable to ordinary rational and social methods of persuasion, Socrates also shows that he recognizes even stronger non-rational methods of remediating the problem. Socrates plainly understands that there is a difference between responding to wrongdoing with the use of rational persuasion, which he characterizes as instruction in the Apology, and contrasts to the kinds of punishments that are mandated in legal contexts (Apology 26a1-8). As for such legal mandates, Socrates is well aware that these may include such things as "blows or bonds", but insists that they are nonetheless to be endured when the state commands them (Crito 51b6). $\mathrm{He}$ is willing to give Hippias the impression 
that some things he (Socrates) might say would merit a beating (Hippias Major 292b5-6). But several passages in the Gorgias - which, again, seems to be the dialogue in which Socrates' recognition of and responses to non-rational sources of belief is the most prominent - make his approval of physical punishments explicit. Two of these are worth attention here. In the first, Socrates explains to Polus what he takes the real value of rhetoric to be:

If he or whomever else he may care about commits wrongdoing, he should voluntarily go to wherever he will pay the penalty as soon as possible, to the judge as if to the doctor, eager to take care that the disease of wrongdoing not become chronic and make his soul fester and become incurable. [...] He ought not hide his injustice but bring it out in the open, so that he may pay his due and become well, and it is necessary for him not to act cowardly but to shut his eyes and be courageous, as if he were going to a doctor for surgery or cautery, pursuing the good and noble and taking no account of the pain, and if his injustice is worthy of a beating, he should put himself forward to be beaten, and if to be imprisoned, he should do it, and if to pay a fine, to pay it, and if to go into exile, to go, and if to be killed, he should be killed. (Gorgias 480a6-d2; see also $478 \mathrm{c} 3-\mathrm{e} 4)$

Later in the dialogue, Socrates explains why he thinks such punishments can be useful:

It is fitting for everyone who deserves punishment from another either to become better and to profit from it or to serve as an example to others in order that others, when they see the suffering that they un- dergo will become better out of fear. Those who become better and pay the penalty inflicted on them by gods and men are those who have committed wrongs that are curable. Nonetheless, the benefit comes to them there in Hades through pain and suffering. For it is not possible to be rid of injustice in any other way. (Gorgias 525b1-c1)

These passages obviously endorse forms of punishment the approval of which some scholars have found impossible to attribute to Socrates. So, for example, quite recently Rowe 2007, 34 has claimed that "punishment", or kolazein, for Socrates, is not a matter for the courts but for philosophical dialectic". Rowe 2007, 32 earlier noticed that Socrates contrasts nouthetein (admonishment) with kolazein (punishment) at Apology 26a1-8, but seems to think that Socrates in the Gorgias simply assimilates the two. Thus, Rowe 2007, 36 finds himself able to reach his goal: "My conclusion is that the Socrates of the Gorgias does not endorse flogging, imprisonment, or any other vulgar kind of punishment". Socrates talked as if he endorsed such things only as a rhetorical strategy against Polus and Callicles: "Socrates mounts his argument in the terms he does [...] because they are the terms his opponents, or interlocutors, can readily understand" (Rowe 2007, 34). That such a tactic renders Socrates dishonest or misleading in the way he undertakes his dialectical discussions seems not to concern Rowe.

We are now in a position, however, to avoid attributing to Socrates such a disingenuous way of explaining his views. Instead, aware that there are non-rational processes to which some people can become especially prone by allowing their appetites to become undisciplined, Socrates also recognizes that there can be non-rational ways to check these processes, by a 
kind of opposing application of similar processes: our natural attraction to pleasure will not be so likely to get the best of us if the way it leads us to behave (via, again, the ways in which it inclines us to believe about which of our present options is in our best self-interest) is perceived as being likely to bring us significant pain, instead. Our natural attraction to beauty, to use another example, will not as likely lead us into wrongdoing with someone else's spouse, for example, if we come to associate such wrongdoing with the pains and shames of the punishments to which adulterers are subjected. And our natural aversion to injury and physical suffering will not be as likely to lead us to desert our military post if we become more aware of the shame that would cause us, or even more significant punishments, to which we are even more intensely averse. It would be a nicer world, perhaps, if the only effective remediation for wrongdoing was a calm conversation with someone whose ethics were more reliable than the wrongdoer's own. But Socrates, we claim, is well aware that calm conversation is not always possible, and would not be effective even if it were, and in some cases may therefore not be the best way to change a wrongdoer's choices. This is because such choices can in some cases be traced back to non-rational processes. To bring these under better control, one disciplines the soul through denying it the pleasures to which it is so attracted, and in some cases by bringing to it instead the very things the out-of-control soul would prefer most of all to avoid. This, then, is the ground for Socrates' approval of various painful forms of physical punishment, and also for the non-physical, but nonetheless still quite unpleasant examples of social pressure to which he sometimes quite intentionally subjects his interlocutors.

\section{SUMMARY AND CONCLUSION}

We began this paper with a passage that clearly indicates that Socrates is a cognitivist about emotion. But we have also argued that this cannot very well be all there is to emotion for Socrates. He also seems to think that they can make someone experiencing them resistant to reason. We have proposed that this is because Socrates recognized different etiologies of belief, where some of these included non-rational - veridically unreliable - processes. With this recognition in place, we found that we were better able to explain the differences between people's responses to rational persuasion, where some were more responsive to such persuasion than others. While noting the salvation the craft of measurement would be to any of us, we also wondered why those who lacked this craft were not all equal in their susceptibility to non-rational processes, and the (mostly) faulty beliefs to which these processes give rise and by which these beliefs might persist, even in the face of good reasoning that provided reasons why the beliefs should be abandoned or reversed. We then also reviewed the significant evidence we find in several of our texts in which Socrates seems not only to recognize, but also to endorse the uses of various forms of punishment and behavior modification that seem founded in the use of non-rational processes, such as applications of pain or public humiliation. The upshot, we contend, is at least a coherent whole view about the emotions: That he is a cognitivist about emotion, we have no doubt. But by showing how Socrates thinks the emotions arise and how they can be reckoned with when they interfere with the ability to respond to reason, we believe we have not only done full justice to the relevant texts, but we also shown that Socrates has a richer and more plausible 
account of emotion than alternative, "purely" cognitive accounts would have us believe.

\section{BIBLIOGRAPHY}

Austin 2013: E. A. Austin, 'Corpses, Self-Defense, and Immortality: Callicles' Fear of Death in the Gorgias', «Ancient Philosophy» 33 (2013) 33-52.

Brickhouse - Smith 2002: T. C. Brickhouse - N. D. Smith (eds.) The Trial and Execution of Socrates: Sources and Controversies, Oxford University Press, New York 2002.

Brickhouse - Smith 2010: T. C. Brickhouse - N. D. Smith, Socratic Moral Psychology, Cambridge University Press, Cambridge 2010.

Brickhouse - Smith 2012: T. C. Brickhouse - N. D. Smith, 'Response to Critics', «Analytic Philosophy» 53 (2012) 234-48.

Brickhouse - Smith 2013: T. C. Brickhouse - N. D. Smith, 'Socratic Moral Psychology' in J. Bussanich and N. D. Smith (ed.), The Bloomsbury Companion to Socrates, Bloomsbury, London 2013, 185-209

Cooper 1997: J. M. Cooper (ed.) Plato: Complete Works, Hacket, Indianapolis 1997.

Devereux 1995: D. Devereux, 'Socrates' Kantian Conception of Virtue', "Journal of the History of Philosophy» 33(3) 1995, 381-408.

Hardy 2009: J. Hardy, 'Is Virtue Knowledge? Socratic Intellectualism Reconsidered' in G. Gurtler and W. Wians (ed.), Proceedings of the Boston Area Colloquium in Ancient Philosophy 25, Brill, Leiden 2009, chapter 5 .

Hoesly - Smith 2013: D. Hoesly - N. Smith, 'Thrasymachus: Diagnosis and Treatment', in Notomi, Noburu, and Brisson (ed.), Dialogues on Plato's Politeia (Republic): Selected Papers from the Ninth Symposium Platonicum, Academia Verlag, Sankt Augustin 2013, 60-65.

Levy 2013: D. Levy, 'Socrates vs. Callicles: Examination and Ridicule in Plato's Gorgias', «Plato Journal» 13 (2013) 27-36.

Moss 2005: J. Moss, 'Shame, Pleasure, and the Divided Soul', «Oxford Studies in Ancient Philosophy» 29 (2005), 137-70

Moss 2007: J. Moss, 'The Doctor and the Pastry Chef: Pleasure and Persuasion in Plato's Gorgias', «Ancient Philosophy» 27 (2007) 229-249.
Penner 1990: T. Penner, 'Plato and Davidson: Parts of the Soul and Weakness of Will', in D. Copp (ed.), Canadian Philosophers: Celebrating Twenty Years of the Canadian Journal of Philosophy, «Canadian Journal of Philosophy» Supplementary Volume 16 (1990) 35-72.

Reshotko 2006: N. Reshotko, Socratic Virtue, Cambridge University Press, Cambridge, 2006.

Reshotko 2013: N. Reshotko 'Socratic Eudaimonism', in J. Bussanich - N. D. Smith (ed.), The Bloomsbury Companion to Socrates, Bloomsbury, London 2013, 156-84.

Rowe 2007: C. Rowe, 'A Problem in the Gorgias: How is Punishment Supposed to Help with Intellectual Error?' in C. Bobonich and P. Destrée (ed.) Akrasia in Greek Philosophy, Brill, Leiden and Boston (2007) 19-40.

Sanderman 2004: D. Sanderman, 'Why Socrates Mocks His Interlocutors', «Skepsis» 15 (2004) 431-441.

Woodruff 2000: P. Woodruff, 'Socrates and the Irrational', in N. Smith and P. Woodruff (eds.), Reason and Religion in Socratic Philosophy, Oxford University Press, New York and Oxford (2000) 130-150.

\section{NOTES}

1 By "Socrates" in this paper, we mean only to refer to the character of that name who appears in Plato's "early" or "Socratic" dialogues. For a fuller discussion and defense of this practice, see Brickhouse \& Smith 2010, chapter 1 .

2 Unless otherwise noted, all translations used herein are those found in Cooper 1997. Plato reports that there was some discussion over whether this was properly called "fear" or "dread", with the verdict initially appearing to be that it is more properly called "dread", but the distinction seems to be dropped or ignored in the discussion that follows, with Socrates freely focusing on fear and what is to be feared in the remaining arguments about courage. In the remainder of this paper, accordingly, we will make no attempt to distinguish fear from dread, and intend to make no claims about how or why or even whether they might be different from one another. 3 There has recently been a considerable literature on the topic of Socratic motivational intellectualism. The version represented here is what we have in our earlier work identified as what at least used to be the "standard view" of the Socratic position. In the past 20 years or so, however, there have been an increasing number of challenges to this position, perhaps most importantly starting with Devereux 1995. Devereux argues that the texts also 
indicate that Socrates believed that non-rational desires (in which group he included the emotions) could also explain why people act in some cases. Those opposing Devereux's interpretation have included Terry Penner, Naomi Reshotko, and Christopher Rowe (sometimes in collaborations with one another), who offer a more sophisticated explanation of how cognitions can come into being and also be changed - one that nonetheless maintains that belief creation and change are all responses to new information of some sort. (See notes 5, 6, 7,9 , and 18, below, for specific citations.) For this reason, we have elsewhere called their view the "informational view" of Socratic motivational intellectualism (in Brickhouse \& Smith 2012). Our own understanding of Socratic motivational intellectualism more closely follows Devereux's, though departs from his view on several points. For more complete discussions of all these views, see Brickhouse \& Smith 2010, and Brickhouse \& Smith 2013. We make some important revisions and clarifications in Brickhouse \& Smith 2012. In all of our recent work, however, we have treated the emotions as similar in kind to the appetites (as did Devereux - see above), which we plainly now think is a mistake. A recent clarification of the Penner, Reshotko, and Rowe position is provided by Reshotko 2013. We will be considering some details of the above views in application to the emotions in this paper, but at least one aspect of our argument herein is a significant departure from our own former interpretation, and also that given by Devereux, whose work we followed in this regard: we now no longer accept that Socrates' view of the emotions is appropriately regarded as essentially the same as his view of the appetites. We now recognize Socrates' cognitivism about the emotions (but continue to dispute those who would count him as a cognitivist about the appetites).

4 Austin 2013, 33. Another version of this same insight can be found recently argued in this journal, in Levy 2013. Levy notes, "The overwhelming sense one gets $[. .$.$] is that Socrates is trying to effect some change in$ Callicles not merely by getting him to see that he holds yet another inconsistent set of beliefs, but by doing so in a way designed to shame him" (33). See also Moss 2005.

5 Penner 1990.

6 We include Christopher Rowe and Naomi Reshotko in this group, as having explicitly endorsed Penner's understanding of Socratic intellectualism (see note 3 , above). See also Hardy 2009.

$7 \quad$ Reshotko 2006, 84.

8 See note 3, above, for citations.

9 Reshotko 2006, 86.

10 By citing the Ion as we do here, we assume only that it belongs - as it is usually held to belong - to the group of dialogues included in the "early" or "Socratic" group. In the remainder of this paper, we provide evidence from various other dialogues that confirms our use of the Ion to get a sense of Socrates' conception of the emotions and what their sources might include.

11 All translations from the Apology are from

Brickhouse \& Smith 2002.
13 For an argument to this effect, see Hoesly \& Smith 2013.

14 Our interest in this paper is in the non-rational (veridically unreliable) aspects of the emotions. But we do not mean to claim that Socrates thinks that emotions are always or inevitably unreliable or mistaken. Given the definition of "fear" in the Protagoras with which we began, for example, it is plain enough that an expectation of something bad could be reliable - in cases, for example, where there really was excellent evidence that something bad was likely. The same (at least implicit) acknowledgement that some emotions are apt is indicated in the Apology, where Socrates distinguishes between fearing things that one does not know to be bad, as opposed to those one does know to be bad (Apology b8-cl): Socrates claims there that he will never fear the former, but he makes no claim not to fear the latter. Indeed, given cognitivism about fear, he should not claim not to fear what he knows to be bad, since that would amount to a cognitive mistake-not to fear in such a case would amount to failing to expect something bad even when one knew perfectly well that something bad was in the offing. But as we might expect, and as the same passage from the Apology indicates, at least some emotions are not reliable: people can and do sometimes fear things they have no good reason to fear.

15 Our texts might even provide an example of this sort of phenomenon that is experienced by Socrates himself, when he reacts erotically to the exposed thigh of the young Charmides, but then forces himself to regain self-control (Charmides 155c5-e3).

16 The question raised implicitly here is the very one Socrates discusses with Protagoras and also elsewhere with Meno: Can virtue be taught, and if not, how else might it be acquired? Nothing in our texts makes such an achievement seem likely.

17 For discussion of how we are to understand this process, see Brickhouse \& Smith 2010, chapter 4.

18 So see, esp. Rowe 2007. More of our differences with Rowe's view follow below.

19 So see, for particularly good examples, Woodruff 2000, Sanderman 2004, Moss 2007, and most recently, Levy 2013.

20 Woodruff 2000 is especially good in bringing this social dimension out, and also at identifying its nonrational aspect. 